\title{
Formation of Active Derivatives of Glucoamylase I during the Digestion with Fungal Acid Protease and $\alpha$-Mannosidase
}

\author{
Shinsaku HAYASHIDA and Eiichi Yoshino \\ Department of Agricultural Chemistry, Kyushu University, \\ Fukuoka, Japan
}

Received August 8, 1977

\begin{abstract}
Glucoamylase I (MW 90,000; N-terminal alanine) was selectively produced by a submerged culture of Aspergillus awamori var. kawachi as an enzyme having the ability to digest even raw starches, and was converted into a modified active glucoamylase decreasing in molecular weight during the digestion with the acid protease of the same mold strain. The modified glucoamylase (MW 83,000; N-terminal alanine plus isoleucine) was resembled to an intermediate type of glucoamylase $\mathrm{I}^{\prime}$, and exhibited hydrolysis curves for gelatinized potato starch and maltose in the same manner as that of glucoamylase I; but it did not digest raw starches and was not adsorbed onto cornstarch, and showed the lower hydrolysis limit of 80 percent for glycogen. The carbohydrate contents of glucoamylase I decreased 59 percent during the digestion with fungal $\alpha$-mannosidase. The carbohydrate-split glucoamylase (MW 86,000; Nterminal alanine) was unstable at $\mathrm{pH} 9$ or at $65^{\circ} \mathrm{C}$ in the same extent as glucoamylase $\mathrm{I}^{\prime}$, but was identical with glucoamylase $\mathbf{I}$ in the hydrolysis curves for various substrates, the digestibility for raw starches and the adsorbability onto cornstarch. Multiple forms of glucoamylase were observed when native glucoamylase I was degraded stepwisely with fungal acid protease and $\alpha$-mannosidase.
\end{abstract}

Three types of glucoamylases, glucoamylase I, $I^{\prime}$ and II, are isolated from the culture of a single mold strain, and have shown different hydrolysis curves for substrates. ${ }^{1 \prime}$ Glucoamylase $I$ is suggested to be the prototype of glucoamylase, because the other two types are derived in vitro from glucoamylase $\mathrm{I}^{2)}$ Glucoamylase I (MW 90,000) has been purified from the filtrate of a less protease-producing culture, "Culture A" of Aspergillus awamori var. kawachi. It digests raw cornstarch completely, and also hydrolyzes gelatinized potato starch and glycogen to a degree of 90 percent and 100 percent respectively. It is also found $^{2}$ that when glucoamylase $\mathrm{I}$ is digested with subtilisin in $0.01 \mathrm{~N}$ phosphate buffer, $\mathrm{pH}$ 6.8 at $30^{\circ} \mathrm{C}$, the molecular weight and the carbohydrate content of the enzyme decrease and it is converted to a modified active enzyme. The subtilisin-modified glucoamylase (MW 83,000) shows the same hydrolysis curves for gelatinized potato starch and maltose as those of glucoamylase I, but it completely lose the ability to digest raw starches and to ad- sorb onto cornstarch. These properties are identical with glucoamylase I'. An intermediate type of glucoamylase, glucoamylase $\mathrm{I}^{\prime}$ (MW 83,000) is produced selectively in " $\mathrm{Cul}$ ture B" of Aspergillus awamori var. kawachi, which has a high activity of acid protease. Glucoamylase $I^{\prime}$ does not digest any raw starches and shows a hydrolysis limit of 80 percent for glycogen. However, the activity of this enzyme for hydrolyzing gelatinized potato starch and maltose is the same as that of glucoamylase I. The third type, glucoamylase II (MW 57,000) is selectively produced in "Culture C," which has higher level of activities of protease and glycosidase. Glucoamylase II does not digest raw starches, and shows the hydrolysis limits of 60 percent and 40 percent for gelatinized potato starch and glycogen, respectively. ${ }^{11}$

In this paper, it is described that the formation of a modified glucoamylase quite similar to glucoamylase $\mathbf{I}^{\prime}$ in properties is observed during the digestion of glucoamylase I with the acid protease of Aspergillus awamori var. 
kawachi, the same strain as that of producing glucoamylase, and that the formation of the heat unstable carbohydrate-split glucoamylase is observed during the digestion of glucoamylase I with fungal $\alpha$-mannosidase.

\section{MATERIALS AND METHODS}

Preparations of glucoamylase $I$ and $I^{\prime}$. Aspergillus awamori var. kawachi was cultured in a 30-liter jar fermentor under the condition of "Culture $A$ " or "Culture B" as reported previously, 1 " to produce selectively either type I or type I' of glucoamylase in the culture filtrate, respectively. The purification of each enzyme was carried out by the modified method given in the previous paper. ${ }^{1)}$ After removal of rivanol with acid clay, the enzyme was fractionally precipitated with ammonium sulfate; glucoamylase type I was precipitated at a concentration of $35 \%$ to $45 \% \mathrm{w} / \mathrm{v}$, and type $\mathrm{I}^{\prime} 45 \%$ to $55 \%$, respectively. The precipitate was dissolved in deionized water, desalted by filtration through a Sephadex G-50 column and then lyophilized. The sample was applied on a DEAE-Sephadex A-50 column $(1.5 \times 45 \mathrm{~cm})$ previously saturated with $0.05 \mathrm{M}$ phosphate buffer (S申rensen type) of pH 5.5. Chromatography was conducted by a linear gradient elution with a system composed of $250 \mathrm{ml}$ of the same buffer in a mixing vessel and $250 \mathrm{ml}$ of $1 \mathrm{M}$ phosphate buffer of $\mathrm{pH} 5.5$ in a reservior. Fractions having a volume of $5 \mathrm{ml} /$ tube, were collected at $4^{\circ} \mathrm{C}$ at a flow rate of $10 \mathrm{ml}$ per hour. The activity of glucoamylase type I appeared in fractions 50 to 60 and that of type $I^{\prime}$ in 25 to 35 , respectively, and each type was concentrated in a collodion bag (SM 13200, in Sartorious-membranefilter $\mathrm{GmbH}$, Goettingen), desalted by the filtration through a Sephadex G-50 column and lyophilized. The lyophilized sample was designated as glucoamylase I or glucoamylase $I^{\prime}$, giving a single protein band in disc electrophoresis on polyacrylamide gel, respectively.

Determination of the type of glucoamylases. The type of the enzyme was determined from the hydrolysis curves for gelatinized potato starch, glycogen and raw cornstarch, as described in the previous paper. ${ }^{1)}$ The adsorption rates of glucoamylase activity on raw cornstarch were supplementally used for determining the types. ${ }^{1)}$

Digestions with acid proteases. Three kinds of acid proteases were prepared and incubated with native glucoamylase I. Glucoamylase I (4 mg) was dissolved in $4 \mathrm{ml}$ of $0.05 \mathrm{M}$ citrate ( $\mathrm{pH} \mathrm{3)}$, acetate ( $\mathrm{pH} 4)$ and phosphate (pH's 5,6 and 7) buffers respectively. The digestion was performed at $30^{\circ} \mathrm{C}$ for $24 \mathrm{hr}$, with the $0.4 \mathrm{mg}$ of a lyophilized preparation of each acid pro- tease free from amylase activity completely. "Proctase," an acid protease preparation of Aspergillus niger, supplied kindly from Meiji-Seika Co., was further purified by DEAE-Sephadex column chromatography, "Molsin," an acid protease preparation of Aspergillus saitoi, supplied kindly from Seishin Pharmaceutical Co. by Duolite CS-101 column chromatography, and the "Culture B" of Aspergillus awamori var. kawachi, by Duolite CS-101 and DEAE-Sephadex column chromatography. Each preparation showed an optimum $\mathrm{pH}$ of 2.5 to 3.0 , and the typical properties of acid protease. ${ }^{3}$ The modification degree of glucoamylase $I$ was determined by decreasing in the adsorption rate onto cornstarch granules. The acid protease-modified glucoamylase was applied to a DEAE-Sephadex A-50 column and fractionated as described previously. ${ }^{1)}$ The desalted and lyophilized sample was designated as acid protease-modified glucoamylase.

N-Terminal analysis. Manual Edman degradation was carried out by the procedure modified by Iwanaga et al. ${ }^{4)}$ The PTH-amino acids were identified by thin-layer chromatography on a silica gel plate with Solvent $V_{M}$.

Digestions with $\alpha$-mannosidase. Glucoamylase I (500 mg) was dissolved in $10 \mathrm{ml}$ of $0.05 \mathrm{M}$ phosphate buffer, pH 5.25, and digested with $5 \mathrm{mg}$ of the lyophilized preparation of Trichoderma $\alpha$-mannosidase (600 $\mathrm{u} / \mathrm{mg})^{5\rangle}$ free from amylase and protease activities, at $20^{\circ} \mathrm{C}$ for 6 days. For $\alpha$-mannosidase, "Meicellase" supplied kindly from Meiji-Seika Co. was further purified by DEAE-Sephadex A-50 column chromatography. The digested glucoamylase was collected by the same procedure as described above.

\section{RESULTS}

\section{Formations of acid protease-modified gluco- amylases}

The respective digestions of native glucoamylase I with three kinds of acid proteases from different species of black Aspergilli were performed at the various pH's. The modifications occurred in a broad range of $\mathrm{pH}$ from 3 to 7 , as shown in Table I, though glucoamylase I was less susceptible to the modifications at $\mathrm{pH} 4$, close to the isoelectric point of the enzyme. As three proteases showed almost the same results, the acid protease of Aspergillus awamori var. kawachi was used at $\mathrm{pH} 5.0$ in the following experiments. The digested sample bufferized at $\mathrm{pH} 5.0$ was applied to a 
Table I. Changes in adsorption Rates of Glucoamylase by InCUBATIONS With Acid Proteases

( ) shows the inactivation rates of glucoamylase activity $(\%)$ by incubations with each acid protease at $30^{\circ} \mathrm{C}$ for $24 \mathrm{hr}$. The control glucoamylase I showed the adsorption rate of $100 \%$.

\begin{tabular}{lccccc}
\hline \multirow{2}{*}{$\begin{array}{c}\text { Sources of acid } \\
\text { proteases }\end{array}$} & \multicolumn{5}{c}{$\begin{array}{c}\text { Adsorption rates (\%) after } \\
\text { incubations at }\end{array}$} \\
\cline { 2 - 6 } & $\mathrm{pH} \mathrm{3}$ & $\mathrm{pH} 4$ & $\mathrm{pH} 5$ & $\mathrm{pH} 6$ & $\mathrm{pH} 7$ \\
\hline $\begin{array}{c}\text { Aspergillus niger } \\
\text { (Proctase) }\end{array}$ & 0 & 27 & 0 & 0 & 0 \\
$\begin{array}{c}\text { Aspergillus saitoi } \\
\text { (Molsin) }\end{array}$ & 0 & 31 & 0 & 0 & 0 \\
Aspergillus awamori & 0 & 35 & 0 & 0 & 0 \\
var. kawachi & $(31)$ & $(13)$ & $(28)$ & $(30)$ & $(30)$ \\
(Culture B) & & & & & \\
\hline
\end{tabular}

DEAE-Sephadex A-50 column $(1.5 \times 45 \mathrm{~cm})$ at $4^{\circ} \mathrm{C}$. Two protein peaks were distributed over 15 to 23 and 25 to 45 fractions, which coincided with carbohydrate contents, as shown in Fig. 1. The first glycopeptide peak had no glucoamylase activity as described in the previous paper. ${ }^{2)}$ The second peak having glucoamylase activity was suggested to be a modified enzyme, because the peak was eluted faster than that of the native one. The activity decreased about 25 percent, when the digestion had terminated, as recognized in the modification by subtilisin. The result of poly-

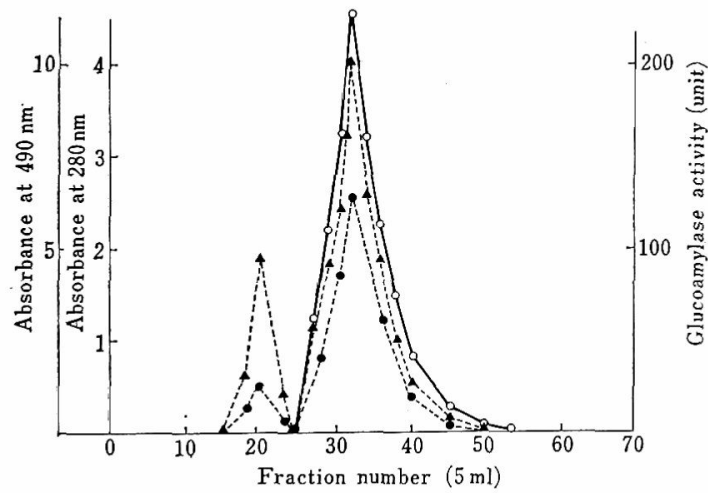

FIG. 1. DEAE-Sephadex Column Chromatography of the Digested Sample of Glucoamylase I with Acid Protease.

The experimental details are described in the text; $0-0$, glucoamylase activity; $\mathbf{\Delta - - - \Lambda}$, absorbance at $490 \mathrm{~nm}$ after adding the phenol-sulfuric acid reagent; ----e, absorbance at $280 \mathrm{~nm}$.

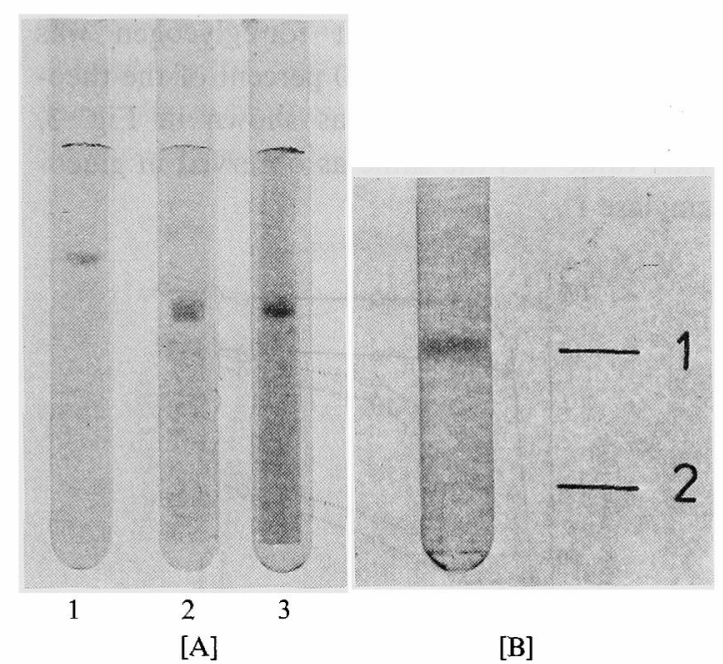

FIG. 2. Gel Electrophoretic Patterns of Acid Protease-modified Glucoamylase.

[A] SDS-polyacrylamide gel electrophoresis was performed by the procedure described previously. ${ }^{2)}$ 1: Glucoamylase I; 2: Glucoamylase I'; 3 : Modified glucoamylase shown as a contrast, respectively.

[B] Analytical disc gel electrophoresis was carried out on a $7.5 \%$ polyacrylamide gel column with a Tris buffer system, $\mathrm{pH}$ 8.3. About $20 \mu \mathrm{g}$ of modified glucoamylase was applied and run at a constant current of $2 \mathrm{~mA}$ per column $(0.5 \times 8 \mathrm{~cm})$ for $120 \mathrm{~min}$. The gel was stained with $1 \%$ Amido Schwarz 10B. 1: Modified glucoamylase; 2: Marker BPB.

acrylamide gel electrophoresis of the digested sample is shown in Fig. 2, indicating only one component upon the gel, identical with glucoamylase $\mathrm{I}^{\prime}$.

Comparisons of properties between the acid protease-modified glucoamylase and glucoamylase $I^{\prime}$

1) Raw starch digestibility. Glucoamylase I catalyzed the hydrolysis of raw cornstarch, but glucoamylase $\mathrm{I}^{\prime}$ did not. The modified enzyme lost completely the abilities to digest raw starches and to be adsorbed onto cornstarch granules. These properties were identical with those obtained in the subtilisin-modified glucoamylase. $^{2 !}$

2) Hydrolysis curves for various substrates. Hydrolysis curves of the modified enzyme for both gelatinized potato starch and maltose were almost the same as those of glucoamylase I, 
but the hydrolysis limit for glycogen was lowered to an extent of 80 percent of the theoretical yield of glucose as shown in Fig. 3. This value was the same as observed in glucoamylase $\mathbf{I}^{\prime}$.

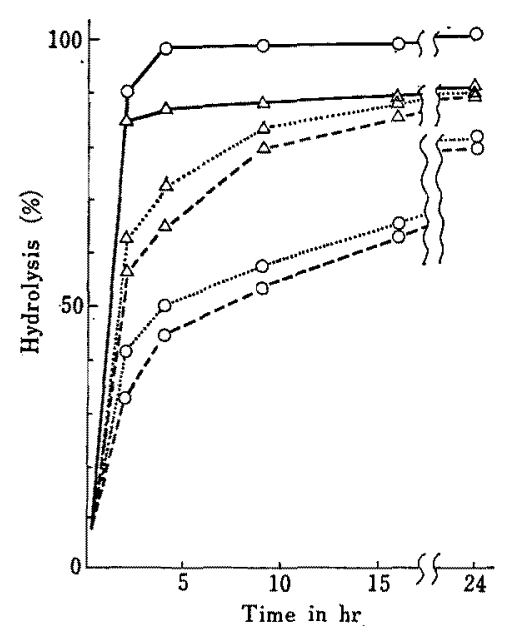

Fig. 3. Hydrolysis Curves of Acid Protease-modified Glucoamylase and Glucoamylase I'.

The reaction mixture consisting of $5 \mathrm{ml}$ of $1 \%$ cooked solution of amylaceous substrate, $1 \mathrm{ml}$ of $0.1 \mathrm{M}$ citrate buffer ( $\mathrm{pH} 4.0$ ), $1 \mathrm{ml}$ of deionized water and $1 \mathrm{ml}$ of enzyme solution, was incubated at $30^{\circ} \mathrm{C}$. - , glucoamylase $\mathrm{I}$; ---, modified enzyme; $\cdots . .$. , glucoamylase $\mathrm{I}^{\prime} ; \Delta$, gelatinized potato starch; $O$, glycogen.

3) Stabilities. For the measurement of $\mathrm{pH}$-stability, glucoamylase I $(10 \mu \mathrm{g})$ and the modified enzyme $(12 \mu \mathrm{g})$ were dissolved in the following buffer systems $(1 \mathrm{ml}), \mathrm{S} \phi$ rensen's citrate ( $\mathrm{pH} 1.5 \sim 5.0$ ), S $\phi$ rensen's phosphate $(\mathrm{pH} 5.0 \sim 8.0)$ and Clark's borate $(\mathrm{pH} 8.0 \sim$ $10)$, respectively. The mixture was kept at $30^{\circ} \mathrm{C}$ for $20 \mathrm{hr}$. Then, the residual activity was measured under the standard assay conditions. The modified enzyme was less stable than glucoamylase I and the pH stability curve was coincided with that of glucoamylase $I^{\prime}$, as shown in Fig. 4. For the measurement of thermal stability, aliquots of the enzyme solutions prepared in $0.1 \mathrm{~N}$ of phosphate buffer of $\mathrm{pH} 5.5$, were kept for $30 \mathrm{~min}$ at the indicated temperatures. The results are shown in Fig. 5. The modified enzyme was less stable than glucoamylase I at higher temperature than

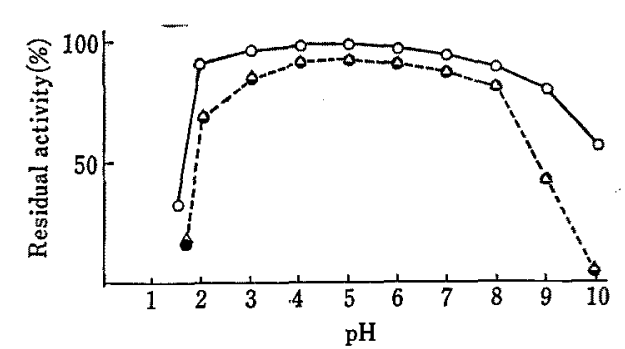

FIG. 4. pH-Stabilities of Acid Protease-modified Glucoamylase and Glucoamylase I'.

The enzyme activity was measured after allowing the reaction mixture to stand at $30^{\circ} \mathrm{C}$ for $20 \mathrm{hr}$ at various pH's; O-O, glucoamylase I; --- , modified enzyme; $\triangle--\triangle$, glucoamylase $\mathrm{I}^{\prime}$.

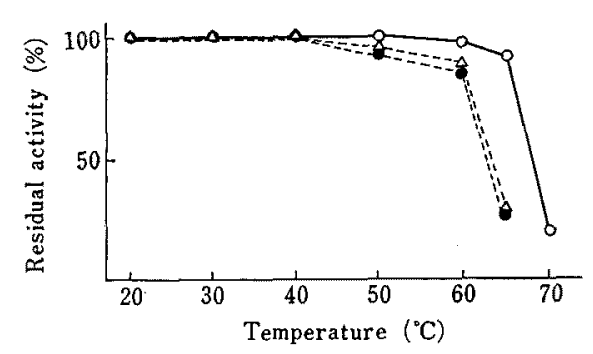

FIG. 5. Thermal Stabilities of Acid Protease modified Glucoamylase and Glucoamylase I'.

The enzyme activity was measured after allowing the reaction mixture to stand at $\mathrm{pH} 5.5$ for $30 \mathrm{~min}$ at various temperatures. The residual activity was expressed as percent of the untreated contol; $\mathrm{O}-\mathrm{O}$, glucoamylase I; ---0, modified enzyme; $\triangle--\Delta$, glucoamylase $I^{\prime}$.

$60^{\circ} \mathrm{C}$. The inactivation curve of the modified enzyme was the same as that of glucoamylase I'.

4) Sedimentation coefficient. Sedimentation coefficient $\left(s_{20, w}\right)$ of the modified enzyme and glucoamylase I' calculated from the sedimentation patterns was $4.6 \mathrm{~S}$.

5) Molecular weight. Molecular weights were measured according to the procedure of Weber and Osborn ${ }^{6}$ ) that polyacrylamide gel electrophoresis was performed in the presence of sodium dodecyl sulfate. The molecular weight of modified enzyme and glucoamylase I' was identical and estimated to be 83,000 .

6) Isoelectric point. The electrofocussing electrophoresis on Carrier ampholyte $(\mathrm{pH} 2.5$ to 4.0) was performed according to Vesterberg et $a .^{7}{ }^{7}$ The isoelectric point of the modified enzyme was 3.45 and that of glucoamylase $I^{\prime}$ 
was also 3.45 .

7) N-Terminal amino acids. Glucoamylase I was subjected to manual Edman degradation and the $\mathrm{N}$-terminal amino acid was determined to be alanine. N-Terminal amino acids of the modified enzyme were identified as alanine and isoleucine. And the same amino acids were also identified from the $\mathrm{N}$ terminal of glucoamylase I'.

8) Carbohydrate content. Each enzyme $(1 \mathrm{mg})$ was dissolved in $10 \mathrm{ml}$ of deionized water. To $1 \mathrm{ml}$ of the enzyme solution were added $1 \mathrm{ml}$ of the phenol reagent and $5 \mathrm{ml}$ of conc. sulfuric acid. When the carbohydrate content was calculated from the absorbance at $490 \mathrm{~nm}$ using mannose as standard, it is determined to be 4.8 percent as mannose in both the modified enzyme and glucoamylase $\mathrm{I}^{\prime}$, whereas 7.6 percent in glucoamylase $\mathrm{I}$.

\section{Effects of a-mannosidase on glucoamylase I}

When glucoamylase I was incubated with the amylase- and protease-free preparation of Trichoderma $\alpha$-mannosidase, the liberation of mannose was observed. The digested sample was applied to a DEAE-Sephadex A-50 column. The activity was distributed over 40 to 65 fractions, as shown in Fig. 6, and the eluted position was almost the same as that of

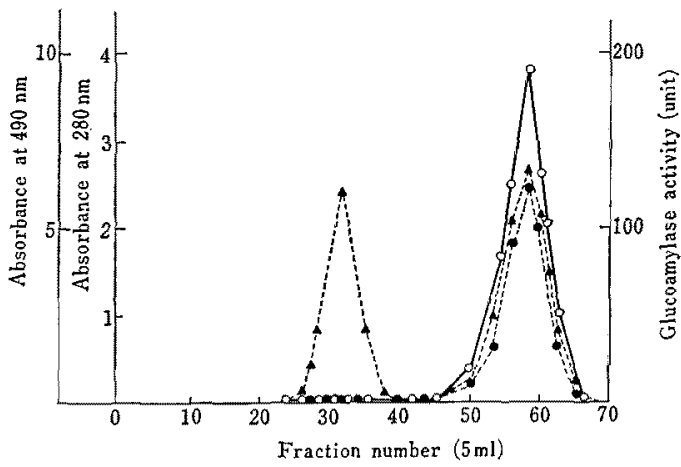

FIG. 6. DEAE-Sephadex Column Chromatography of the Digested Sample of Glucoamylase I with $\alpha-$ Mannosidase.

The experimental details are the same as described in Fig. 1; $\mathrm{O}-\mathrm{O}$, glucoamylase activity; $\mathbf{\Delta - - \Delta , a b -}$ sorbance at $490 \mathrm{~nm}$ after adding the phenol-sulfuric acid reagent; the undigested glucoamylase I. Fifty nine percent of the carbohydrate moiety was lost from the sufficiently digested glucoamylase, therefore the carbohydrate content of this

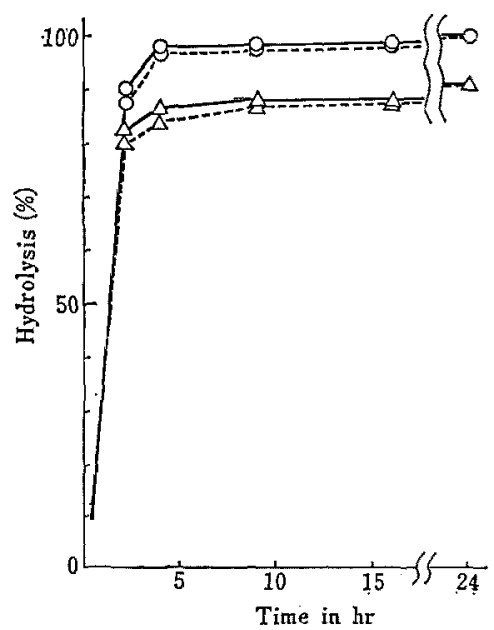

Fio. 7. Hydrolysis Curves of Native and Carbohydrate-split Glucoamylases.

The experimental conditions are the same as in Fig. 2; - - native enzyme; - - - , modified enzyme; $\triangle$, gelatinized potato starch; $O$, glycogen.

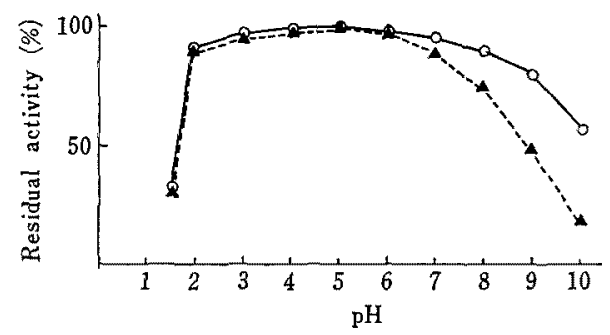

FIG, 8. pH-Stabilities of Native and Carbohydratesplit Glucoamylases.

The experimental conditions are the same as in Fig. 3; $\bigcirc-O$, native enzyme; $\boldsymbol{\Delta}--\boldsymbol{A}$, modified enzyme.

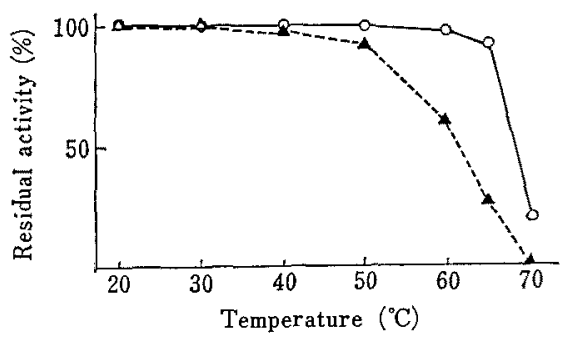

FIG. 9. Thermo-stabilities of Native and Carbohydrate-split Glucoamylases.

The experimental conditions are the same as in Fig. 4;

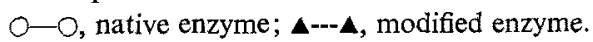


preparation was 3.0 percent as mannose. The molecular weight of the digested glucoamylase I became 86,000 . The $\mathrm{N}$-terminal amino acid was alanine. The hydrolysis curves of the carbohydrate-split glucoamylase for gelatinized potato starch, glycogen and maltose were the same as those of glucoamylase I, but the stabilities lowered at $\mathrm{pH} 9$ and at higher temperature than $50^{\circ} \mathrm{C}$ respectively, as shown in Figs. 7, 8 and 9. These properties were identical with those of glucoamylase I'.

\section{DISCUSSION}

Glucoamylase I was digested with acid protease to produce the acid protease-modified glucoamylase. The properties of the modified enzyme were the same as those of glucoamylase I'. The properties we investigated were the elution pattern of DEAE-Sephadex A-50 column, raw starch digestibility, adsorbability onto cornstarch, hydrolysis curves for various substrates, $\mathrm{pH}$ and thermal stabilities, Nterminal amino acids, sedimentation coefficient, molecular weight, isoelectric point and carbohydrate content. The fact that both the enzymes had the same properties would indicate that glucoamylase I was modified to glucoamylase $\mathrm{I}^{\prime}$ by the action of fungal acid protease in a broad range of $\mathrm{pH}$ from 3 to 7 . The properties of acid protease-modified glucoamylase coincided also in the abovementioned items with the subtilisin-modified glucoamylase which was prepared from glucoamylase I by digestion with subtilisin as previously reported. ${ }^{2)}$ The homogenity of glucoamylase I was confirmed by disc polyacrylamide gel electrophoresis. The purified glucoamylase I showed the complete adsorbability onto cornstarch and had only one $\mathrm{N}$-terminal amino acid, alanine. These evidence would indicate that this enzyme consists of a single peptide chain. A new Nterminal amino acid, isoleucine, accompanying the liberation of a glycopeptide, was obtained by the proteolytic digest. These results suggest that the specific two peptide bonds located apart from the active site on a molecule of native glucoamylase I were susceptible to the microbial proteases.

The carbohydrate moiety of glucoamylase I, composed of mannose and a small amount of $\mathrm{N}$-acetylglucosamine, was partially hydrolyzed by Trichoderma $\alpha$-mannosidase. Although the content of carbohydrate decreased to 41 percent in the carbohydrate-split glucoamylase, the hydrolysis curves for soluble substrates and raw starches did not change, but the enzyme became unstable for $\mathrm{pH}$ and temperature changes. This fact would indicate that the multiple forms of glucoamylase occurred also with $\alpha$-mannosidase, because though molecular weight, the carbohydrate content and stabilities of these enzymes were different, yet the hydrolysis curves were identified among them. The carbohydrate moiety was considered to be related to the stability of the enzyme. As previously described, the proteolysis of the protein moiety of glucoamylase I caused the conversion to the other type of glucoamylase; the selective submerged production of each type of glucoamylase was correlated to the accompanied protease in the culture. All the data supported our hypothsis that the stepwise degradations of a native glucoamylase I with proteases and glycosidases may proceed in the course of mold cultivation and enzyme preparation, leading to the formation of multiple forms of glucoamylase. The formation of a modified glucoamylase identical with glucoamylase II (MW 57,000), by the cooperative actions of protease and glycosidase on glucoamylase I, will be described in the next paper.

Acknowledgment. Greatful acknowledgment is made to Emeritus Professor Dr. M. Hongo for his constant interest and guidance in this investigation. Thanks are due to Meiji-Seika Co. and Sheisin-Seiyaku Co., for providing purified preparations of protease and glycosidase.

\section{REFERENCES}

1) S. Hayashida, Agric. Biol. Chem., 39, 2093 (1975).

2) S. Hayashida, T. Nomura, E. Yoshino and $M$. Hongo, ibid., 40, 141 (1976). 
3) E. Ichishima and F. Yoshida, Biochim. Biophys. Acta, 99, 360 (1965)

4) S. Iwanaga, P. Wallen, N. J. Groendahl, A. Henschen and B. Blombaeck, Eur. J. Biochem., 8, 189 (1969).

5) T. Muramatsu, J. Biochem. (Tokyo), 62, 700
(1967).

6) K. Weber and M. Osborn, J. Biol. Chem., 244, 4406 (1969).

7) O. Vesterberg and H. Svensson, Acta Chem. Scand., 20, 820 (1966). 